\title{
Urgensi Hukum Perikatan Islam dalam Penyelesaian Sengketa Ekonomi Syariah
}

\author{
Oleh: Achmad Fauzi ${ }^{1}$
}

\begin{abstract}
This article is aimed to oversee sharia economic legal lawsuit through litigation in court with analyzing judge capability in this lawsuit. This issue is important because every sharia economic activities is based on what contract (akad) contains. The article analyses law of engagement based on Indonesia civil law or Borgelijk Wetboek (BW), law of convention based on sharia economic law compilation, sharia court authority, and sharia economic lawsuit solution steps through litigation. It concludes that a judge should able to dig material justice, including in civil law so her/his decision aimed to reform and invention of law (rechtsvinding). As a new jurisdiction to sharia court, sharia economic lawsuit has still a few law instruments that imply the need for a judge to oversee justice values living in people. Formulation of sharia economic law decision should not be separated from sharia law of engagement.
\end{abstract}

Keywords: sharia economic, sharia law, legal, civil law, jurisdiction.

\section{Pendahuluan}

Ada dua opsi yang ditempuh dalam penyelesaian sengketa ekonomi syari'ah, yakni melalui proses litigasi di pengadilan atau non litigasi. Pengadilan Agama adalah lembaga kekuasaan kehakiman yang memiliki kewenangan absolut untuk memeriksa dan mengadili sengketa ekonomi syariah. Hal ini sesuai dengan asas personalitas keislaman dan ketentuan peraturan perundang-undangan yang berlaku (Pasal 49 huruf i Undang-Undang No. 3 tahun 2006 tentang Peradilan Agama dan Pasal 55 angka 1 Undang-Undang No. 21 tahun 2008 tentang Perbankan Syariah). Sedangkan jalur non litigasi meliputi bentuk alternatif penyelesaian sengketa (Alternative Dispute Resolution) dan arbitrase. Alternative Dispute Resolution (ADR) merupakan lembaga penyelesaian sengketa atau beda pendapat melalui prosedur di luar pengadilan dengan cara konsultasi, negosiasi, mediasi, konsiliasi, atau penilaian ahli (Pasal 1 angka 10 UU No.30 Tahun 1999). ${ }^{2}$

Sedangkan arbitrase harus dilakukan melalui Badan Arbitrase Syariah Nasional (Basyarnas) sebagai badan yang berkompeten menegakkan hukum Islam. ${ }^{3}$

\footnotetext{
${ }^{1}$ Hakim Pengadilan Agama Balikpapan, alumnus Fakultas Ilmu Agama Islam UII Jogjakarta. email: suhuf_esoterika@yahoo.com

${ }^{2}$ Alternative Dispute Resolution (ADR)/Alternatif Penyelesaian Sengketa(APS) dalam tata hukum nasional telah mendapatkan legalitas perundang-undangan yang disahkan pada tanggal 12 Agustus 1999, yakni Undang-Undang No. 30 Tahun 1999 Tentang Arbitrase dan Alternatif Penyelesaian Sengketa.

${ }^{3}$ Badan Arbitrase Syariah Nasional (Basyarnas) berdiri secara otonom dan independen sebagai salah satu instrumen hukum yang menyelesaikan perselisihan antar pihak, baik yang datang dari dalam lingkungan bank syariah, asuransi syariah, maupun pihak lain yang memerlukannya. Bahkan, dari kalangan non muslim pun dapat memanfaatkan Badan Arbitrase Syariah Nasional (Basyarnas) sepanjang yang bersangkutan mempercayai kredibilitasnya dalam menyelesaikan sengketa.
} 
Achmad Fauzi: Urgensi Hukum Perikatan Islam...

Pengadilan Agama tidak memiliki kompetensi untuk memeriksa dan mengadili kembali terhadap materi atau substansi perkara ekonomi syariah yang telah diselesaikan melalui jalur non litigasi. Pengadilan Agama hanya memiliki kewenangan melakukan eksekusi atas keputusan Basyarnas yang dimohonkan oleh pihak yang bersengketa.

Sebagian kalangan berpemikiran bahwa proses litigasi cenderung menghasilkan kesepakatan yang bersifat adversarial yang belum mampu merangkul kepentingan bersama, terkesan menimbulkan masalah baru, lambat dalam penyelesaiannya, membutuhkan biaya mahal, tidak responsif, dan menimbulkan permusuhan di antara pihak yang bersengketa. Sedangkan melalui proses di luar pengadilan menghasilkan kesepakatan yang bersifat "win-win solution", dijamin kerahasiaan sengketa para pihak, dihindari kelambatan yang diakibatkan karena hal prosedural dan administratif, menyelesaikan masalah secara komperehensif dalam kebersamaan dan tetap menjaga hubungan baik. Akan tetapi, di negara-negara tertentu proses peradilan dapat lebih cepat. Satu-satunya kelebihan proses non litigasi ini adalah sifat kerahasiaannya, karena proses persidangan dan bahkan hasil keputusannya pun tidak dipublikasikan.

Pemilihan model penyelesaian sengketa melalui arbitrase harus memenuhi 2 (dua) syarat, yakni: pertama, secara material bahwa yang akan diselesaikan lewat badan arbitrase hanyalah sengketa yang berkenaan dengan bidang perdagangan dan mengenai hak yang menurut hukum dan peraturan perundang-undangan dikuasai sepenuhnya oleh pihak yang bersengketa, dan bukan mengenai sengketa yang tidak dapat diadakan perdamaian; kedua, secara formal bahwa klausula tersebut harus dinyatakan secara tertulis dalam akad pada saat kedua belah pihak akan melakukan transaksi ekonomi syari'ah, atau dibuat setelah timbul sengketa antara kedua pihak. Hal inilah yang disebut dengan perjanjian arbitrase, yakni suatu kesepakatan berupa klausula arbitrase yang tercantum dalam suatu perjanjian tertulis yang dibuat para pihak sebelum timbul sengketa, atau suatu perjanjian arbitrase tersendiri yang dibuat para pihak setelah timbul sengketa (Pasal 1 angka 3 UU No.30 Tahun 1999 Tentang Arbitrase dan Alternatif Penyelesaian Sengketa).

Tulisan ini difokuskan kepada penyelesaian sengketa ekonomi syariah melalui jalur litigasi di pengadilan dengan mengkaji dan menganalisa seberapa penting penguasaan hukum perikatan Islam bagi hakim dalam memutuskan sengketa ekonomi syariah. Hal ini dianggap perlu mengingat segala kegiatan ekonomi syariah terbentuk oleh adanya kesepakatan para pihak untuk mengikatkan diri pada perjanjian, sehingga penyelesaiannya dilakukan berdasarkan isi akad.

\section{Hukum Perikatan dalam Borgelijk Wetboek (BW)}

Secara etimologi Undang-Undang tidak menjelaskan apa yang dimaksud daripada perikatan. Begitu pula Code Civil Perancis maupun Borgelijk Wetboek (BW) Belanda yang merupakan concodantie BW kita. Secara etimologi perikatan (Verbintenis) berasal dari kata kerja "verbinden" yang artinya mengikat (ikatan atau hubungan). Verbintenis bisa disebut dengan istilah perikatan, perutangan, atau perjanjian. Perikatan bisa diartikan juga setuju atau sepakat, dari arti kata overeenkomen. 
Achmad Fauzi: Urgensi Hukum Perikatan Islam...

Menurut terminologi, perikatan merupakan suatu hubungan hukum yang bersifat harta kekayaan antara sejumlah terbatas subyek hukum. Sehubungan dengan itu, seseorang atau beberapa orang dari padanya (debitur atau para debitur) mengikatkan dirinya untuk bersikap menurut cara-cara tertentu atas sesuatu prestasi terhadap pihak yang lain (kreditur atau para kreditur). Jadi unsur-unsur perikatan meliputi hubungan hukum, kekayaan, pihak-pihak dan prestasi.

Apabila debitur tidak melakukan apa yang telah diperjanjikan, maka ia dikatakan melakukan wanprestasi. Kreditur dapat menuntut pemenuhan parikatan, pemenuhan perikatan dengan ganti rugi, ganti rugi, pembatalan persetujuan timbal balik, pembatalan dengan ganti rugi, dan pembatalan debitur yang dituduh lalai.

Seorang debitur yang lalai dapat mengajukan pembelaan diri dengan mengajukan beberapa alasan yang membebaskan hukum, yaitu keadaan memaksa (overmacht/force majure), kreditur juga melakukan kelalaian (exception nonadimpleti contractus), kreditur telah melepaskan haknya untuk menuntut ganti rugi (rechtsverweking).

Jika hukum benda memiliki suatu sistem tertutup, maka hukum perikatan menganut sistem terbuka (Aanvullenrecht). Artinya, para pihak boleh membuat aturan-aturan sendiri yang menyimpang dari pasal-pasal perjanjian. Akan tetapi jika mereka tidak mengatur sendiri, berarti mengenai perkara tersebut, mereka akan tunduk kepada undang-undang. Sistem terbuka yang mengandung asas kebebasan berkontrak disimpulkan dari pasal 1338 KUHPerdata yang berbunyi "Semua perjanjian yang dibuat secara sah berlaku sebagai undang-undang bagi mereka yang membuatnya" (pacta sunt servanda).

Sistem terbuka juga mengandung pengertian bahwa perjanjian-perjanjian khusus yang diatur dalam undang-undang hanyalah merupakan perjanjian yang paling terkenal saja dalam masyarakat pada waktu KUHPer dibentuk.

Dalam hukum perjanjian juga berlaku asas konsensualisme, yakni pada dasarnya perjanjian dan perikatan yang timbul sudah dilahirkan sejak detik tercapainya kesepakatan. Dengan kata lain, perjanjian itu sudah sah dan mengikat apabila telah tercapai kesepakatan mengenai hal yang pokok dari perjanjian itu. Misalnya, mengenai barang dan harga dalam jual beli.

Asas konsensualisme tersebut lazimnya disimpulkan dari ketentuan pasal 1320 KUHPer yang berbunyi "Untuk sahnya suatu perjanjian diperlukan empat syarat; kesepakatan mereka yang mengikat dirinya (the consent of those who bind themselves), kecakapan untuk membentuk suatu perikatan (the capability to make an agreement), suatu hal tertentu (a particular object), suatu sebab yang halal (a lawful cause/oorzaak)". Syarat "kata sepakat dan cakap" disebut sebagai syarat subjektif yang apabila tidak dipenuhi mengakibatkan perjanjian dapat dibatalkan (vernietigbaar). Sedangkan syarat "suatu hal tertentu dan sebab yang halal" disebut sebagai syarat objektif yang apabila tidak dipenuhi menimbulkan perjanjian batal demi hukum (nietig).

\section{Hukum Perjanjian dalam Kompilasi Hukum Ekonomi Syariah (KHES)}

Perjanjian dalam bahasa Arab lazim disebut dengan akad. Dalam pasal 20 angka 1 KHES dirumuskan bahwa akad adalah kesepakatan dalam suatu perjanjian 
Achmad Fauzi: Urgensi Hukum Perikatan Islam...

antara dua pihak atau lebih untuk melakukan atau tidak melakukan perbuatan hukum tertentu. Pada pasal 22 disebutkan rukun akad terdiri atas; pihak yang melakukan akad, objek akad, tujuan pokok akad, dan kesepakatan.

Pihak yang berakad disebut juga subjek hukum. Dalam pasal 1 angka 2 subjek hukum adalah orang perorangan, persekutuan atau badan usaha yang berbadan hukum atau tidak berbadan hukum yang memiliki kecakapan hukum untuk mendukung hak dan kewajiban. Kategori kecakapan dalam pasal 2 ayat 1 dijelaskan bahwa orang dipandang cakap apabila telah berumur sekurang-kurangnya 18 tahun atau pernah menikah. Dalam hal seorang anak belum mencapai umur 18 tahun dapat mengajukan permohonan pengakuan cakap melakukan perbuatan hukum kepada Pengadilan. Jika terbukti dalam persidangan pemohon tidak memenuhi kriteria orang yang cakap hukum, maka menurut pasal 4 perlu mendapat perwalian. Di samping mereka yang masih di bawah umur, pasal dalam KHES juga menentukan perwalian kepada orang dewasa yang dianggap tidak cakap. Hal ini mirip dengan ketentuan $\mathrm{BW}$ terhadap orang yang berada di bawah pengampuan (curatele). Hanya saja dalam KHES tidak dikemukakan dalam hal apa saja orang dapat ditempatkan di bawah pengampuan.

Pasal 6 KHES menentukan kewenangan pengadilan dalam kaitan dengan perwalian. Ayat 1, pengadilan berwenang menetapkan perwalian bagi orang yang dipandang tidak cakap melakukan perbuatan hukum. Ayat 2, pengadilan berwenang menetapkan orang untuk bertindak sebagai wali sebagaimana dimaksud pada ayat 1 . kemudian pada pasal 7 disebutkan bahwa pengadilan dapat menetapkan orang yang berutang berada dalam perwalian berdasarkan permohonan orang yang berpiutang. Kata-kata pengadilan dalam ketentuan di atas harus dibaca Pengadilan Agama/Mahkamah Syariah.

KHES menggunakan istilah Muwalla untuk menyebut orang yang tidak cakap melakukan perbuatan hukum dan ditetapkan dalam perwalian. Lebih lanjut pasal 9 menjelaskan bahwa muwalla dapat melakukan perbuatan hukum yang menguntungkan dirinya, meskipun tidak mendapatkan izin wali; tidak dapat melakukan suatu perbuatan hukum yang merugikan dirinya, meskipun atas izin wali; keabsahan perbuatan hukum muwalla atas hak kebendaannya yang belum jelas akan menguntungkan atau merugikan dirinya bergantung pada izin wali; apabila terjadi perselisihan antara muwalla dengan wali, muwalla dapat mengajukan permohonan ke pengadilan untuk ditetapkan bahwa yang bersangkutan memiliki kecakapan melakukan perbuatan hukum.

Rukun kedua dari akad adalah objek akad. Pasal 24 KHES menyebut bahwa objek akad adalah amwal atau jasa yang dihalalkan dan dibutuhkan oleh masingmasing pihak. Pengertian amwal pada pasal 1 angka 9 adalah benda yang dapat dimiliki, dikuasai, diusahakan dan dialihkan, baik benda berwujud maupun abstrak, baik benda terdaftar maupun tidak terdaftar, benda bergerak atau tidak bergerak, dan hak yang mempunyai nilai ekonomis. Dalam pengertian tersebut dapat dikemukakan macam perbedaan pengertian benda antara lain;

1. Benda berwujud dan tidak berwujud

a. Benda berwujud adalah benda yang dapat diindera (pasal 1 angka 10).

Volume III, No. 1, Juli 2009 
Achmad Fauzi: Urgensi Hukum Perikatan Islam...

b. Benda tidak berwujud adalah segala sesuatu yang tidak adapat diindera (pasal 1 angka 11).

2. Benda bergerak dan tidak bergerak

a. Benda bergerak adalah segala sesuatu yang dapat dipindahkan dari suatu tempat ke tempat lain (pasal 1 angka 12).

b. Benda tidak bergerak adalah segala sesuatu yang tidak dapat dipindahkan dari suatu tempat ke tempat lain yang menurut sifatnya dietntukan oleh Undang-Undang (pasal 1 angka 13).

3. Benda terdaftar dan tidak terdaftar

a. Benda terdaftar adalah segala sesuatu yang kepemilikannya ditentukan berdasarkan warkat yang dikeluarkan oleh pejabat berwenang (pasal 1 angka 14) .

b. Benda tidak terdaftar adalah segala sesuatu yang kepemilikannya ditentukan berdasarkan alat bukti pertukaran atau pengalihan di antara pihak-pihak (pasal 1 angka 15).

Selain itu dalam pasal 1 angka 9 disebutkan juga bahwa amwal adalah hak yang memiliki nilai ekonomis. Uang dan surat berharga masuk dalam ketegori ini. Hanya saja uang bukanlah sebagai komoditas, melainkan sebagai alat pembayaran yang sah.

Rukun ketiga dari akad adalah tujuan pokok akad. Ketentuan khusus tentang hal ini disebutkan pada pasal 25 KHES yang menyatakan bahwa akad bertujuan memenuhi kebutuhan hidup dan pengembangan usaha masing-masing pihak yang melakukan akad. Namun tidak semua tujuan dibenarkan karena tujuan yang dibenarkan hanyalah untuk akad yang sah. Pasal 28 ayat (1) menyatakan akad yang sah adalah akad yang terpenuhi rukun dan syaratnya. Akad tidak sah apabila bertentangan dengan syariat Islam, peraturan perundang-undangan, ketertiban umum, kesusilaan (pasal 26 KHES).

Pasal 27 dan 28 disebutkan bahwa hukum akad terbagi dalam 3 kategori;

1. Akad yang sah adalah akad yang terpenuhi rukun dan syaratnya;

2. Akad yang fasad adalah akad yang terpenuhi rukun dan syaratnya namun terdapat hal lain yang merusak akad tersebut karena pertimbangan maslahat;

3. Akad yang batal adalah akad yang kurang syarat dan rukunnya.

Rukun akad yang keempat adalah kesepakatan. Dalam KHES tidak ditemukan aturan tentang kesepakatannya sendiri, hanya diatur cacatnya sebuah kesepakatan, yakni apabila dalam akad tersebut mengandung unsur ghalat (khilaf), ikrah (paksaan), taghrir (tipuan), dan gubhn (penyamaran).

Berdasarkan hal ini ada 4 hal yang menyebabkan cacatnya sebuah kesepakatan;

1. Ghalath atau khilaf

Pasal 30 menyatakan kekhilafan tidak mengakibatkan batalnya suatu akad kecuali khilaf itu terjadi mengenai hakikat yang menjadi pokok perjanjian; 
Achmad Fauzi: Urgensi Hukum Perikatan Islam...

\section{Ikrah atau paksaan}

Pasal 31 menyatakan paksaan mendorong seseorang untuk melakukan sesuatu bukan berdasar pilihan bebasnya dan pasal 32 menyebutkan bahwa paksaan dapat menyebabkan batalnya akad apabila pemaksa mampu untuk melaksanakannya, pihak yang dipaksa memiliki persangkaan yang kuat bahwa pemaksa akan segera melaksanakan apa yang diancamkannya apabila tidak patuh pada perintah pemaksa, yang diancamkan benar-benar menekan kondisi jiwa orang yang diancam, ancaman akan dilaksanakan secara serta merta, paksaan bersifat melawan hukum.

3. Tagbrirat atau tipuan

Dalam pasal 33 KHES disebutkan bahwa penipuan adalah pembentukan akad melalui tipu daya. Dengan dalih untuk kemaslahatan, tetapi kenyataannya untuk memenuhi kepentingannya sendiri. Pasal 34 menyatakan bahwa penipuan merupakan alasan pembatalan suatu akad.

4. Gubhn atau penyamaran

Pasal 35 KHES menegaskan penyamaran sebagai keadaan yang tidak imbang antara prestasi dengan imbalan prestasi dalam suatu akad.

Abdul Kadir Muhammad menyatakan bahwa faktor yang memengaruhi berlakunya perjanjian adalah karena kekeliruan, perbuatan curang, pengaruh tidak pantas, dan ketidakcakapan dalam membuat perjanjian. ${ }^{4}$

Hal penting lain yang perlu diperhatikan adalah berkenaan dengan asas akad. Pasal 21 menyatakan bahwa akad dilakukan berdasar 11 asas:

a. Sukarela/ikhtiyari (setiap akad dilakukan berdasarkan kehendak para pihak dan bukan karena keterpaksan);

b. Menepati janji/amanah (setiap akad wajib dilaksanakan oleh para pihak);

c. Kehati-hatian/ikhtiyati (setiap akad dilakukan dengan pertimbangan yang matang);

d. Tidak berubah (setiap akad memiliki tujuan yang jelas dan terhindar dari spekulasi);

e. Saling menguntungkan (setiap akad dilakukan untuk memenuhi kepentingan para pihak sehingga terhindar dari manipulasi);

f. Kesetaraan/taswiyah (para pihak yang melaksanakan akad memiliki kedudukan yang setara, memiliki hak dan kewajiban yang simbang);

g. Transparansi (akad dilakukan dengan pertanggungjawaban para pihak secara terbuka);

h. Kemampuan (akad dilakukan sesuai kemampuan para pihak);

i. Kemudahan/taisir (akad memberi kemudahan bagi masing-masing pihak untuk melaksanakannya);

${ }^{4}$ Abdul Kadir Muhammad. 1986. Hukum Perjanjian, (Bandung: Alumni ), hlm. 122. 
Achmad Fauzi: Urgensi Hukum Perikatan Islam...

j. Itikad baik (akad dilaksanakan dalam rangka menegakkan kemaslahatan);

k. Sebab yang halal (akad tidak bertentangan dengan hukum).

Perjanjian yang tidak dilaksanakan dengan itikad baik sering disebut dengan wanprestasi atau ingkar janji. Dalam pasal 36 KHES dikatakan bahwa pihak dikategorikan melakukan ingkar janji apabila tidak melakukan apa yang dijanjikan untuk melakukannya, melaksanakan apa yang dijanjikan namun tidak sebagaimana yang dijanjikan, melakukan apa yang dijanjikan tetapi terlambat, melakukan sesuatu yang menurut perjanjian tidak dibolehkan. Pihak yang ingkar janji menurut pasal 38 KHES dapat dijatuhi sanksi berupa pembayaran ganti rugi, pembatalan akad, peralihan resiko, denda dan pembayaran biaya perkara. Khusus mengenai pembayaran ganti rugi, pasal 39 KHES menyatakan bahwa pembayaran ganti rugi dapat dijatuhkan apabila pihak yang melakukan wanprestasi setelah dinyatakan ingkar janji tetap melakukan ingkar janji, sesuatu yang harus diberikan atau dibuatnya hanya dapat diberikan atau dibuat dalam tenggang waktu yang telah dilampaukannya, pihak yang melakukan ingkar janji tidak dapat membuktikan bahwa perbuatan ingkar janjinya tidak dibawah paksaan.

\section{Kewenangan Absolut Pengadilan Agama terhadap Penyelesaian Sengketa Ekonomi Syariah}

Pengadilan Agama memiliki kewenangan mutlak untuk menyelesaikan perkara ekonomi syari'ah. Hal ini didasarkan atas ketentuan Pasal 49 UU No.3 Tahun 2006 yang menyatakan bahwa: "Pengadilan agama bertugas dan berwenang memeriksa, memutus, dan menyelesaikan perkara di tingkat pertama antara orang-orang yang beragama Islam di bidang perkawinan, waris, wasiat, hibah, waqaf, rakat, infaq, shadaqah, dan ekonomi syari'ah.". Sebelum diundangkannya UU No.3 Tahun 2006 tersebut memang belum pernah ada peraturan perundang-undangan yang secara khusus melimpahkan kewenangan kepada pengadilan tertentu untuk memeriksa dan mengadili perkara ekonomi syari'ah.

Namun demikian, meskipun Pengadilan Agama telah diberi kewenangan untuk memeriksa, mengadili, dan menyelesaikan perkara ekonomi syari’ah, perangkat hukum materiil maupun perangkat hukum formil perlu terus dibenahi. Lahirnya UU No. 21 tahun 2008 tentang Perbankan Syariah dan PERMA No. 02 tahun 2008 tentang Kompilasi Hukum Ekonomi Syariah (KHES) tidak serta merta mencukupi kebutuhan hakim dalam melakukan tugas-tugas barunya, sehingga perlu dilakukan terobosan hukum guna memenuhi perkembangan kebutuhan hukum masyarakat.

Terobosan tersebut adalah pertama: dengan melakukan penafsiran argumentum per analogian (analogi), yakni dengan memperluas berlakunya peraturan perundangundangan yang mengatur tentang kegiatan ekonomi pada umumnya terhadap kegiatan ekonomi syari'ah karena adanya persamaan-persamaan antara keduanya; kedua: dengan menerapkan asas lex posterior derogat legi apriori, yakni bahwa hukum yang baru mengalahkan hukum yang lama. Dengan demikian, maka ketentuanketentuan hukum lama yang dahulu tidak berlaku pada Pengadilan Agama menjadi berlaku karena adanya kesamaan-kesamaan antara keduanya dan aturan-aturan yang berkaitan dengan ekonomi syari'ah yang dahulu bukan menjadi kewenangan 
Achmad Fauzi: Urgensi Hukum Perikatan Islam...

Pengadilan Agama maka sekarang menjadi kewenangan Pengadilan Agama dengan adanya UU No.3 Tahun 2006, sepanjang berkenaan dengan ekonomi syari'ah.

Diantara peraturan perundang-undangan yang mengatur kegiatan ekonomi adalah UU No.30 Tahun 1999 Tentang Arbitrase dan Alternatif Penyelesaian Sengketa (ADR) dan UU No.4 Tahun 1998 Tentang Penetapan Peraturan Pemerintah Pengganti Undang-Undang Nomor 1 Tahun 1998 Tentang Perubahan Atas Undang-Undang Kepailitan. Melalui penafsiran argumentum per analogian (analogi), maka ketentuan UU No.30 Tahun 1999 dan UU No.4 Tahun 1998 tersebut diberlakukan pada Pengadilan Agama. Kata-kata 'Pengadilan Negeri' atau 'peradilan umum' dalam Undang-Undang tersebut dapat diberlakukan pada 'Pengadilan Agama' atau 'peradilan agama' sepanjang menyangkut ekonomi syari'ah. Berbagai ketentuan tentang badan arbitrase dalam Undang-Undang tersebut secara mutatis mutandis diterapkan pada Badan Arbitrase Syari'ah Nasional (Basyarnas) sebagai satu-satunya badan arbitrase dalam ekonomi syari'ah yang ada di Indonesia. Demikian juga halnya tentang kepailitan. Dengan mengadopsi dua Undang-Undang tersebut maka dapat dipakai sebagai pedoman dalam menyelesaikan perkara yang berkaitan dengan alternatif penyelesaian sengketa, arbitrase, dan kepailitan di bidang ekonomi syari'ah pada Pengadilan Agama.

Berdasarkan ketentuan Pasal 49 UU No.3 Tahun 2006 jis UU No.30 Tahun 1999 dan UU No.4 Tahun 1998, maka kewenangan Pengadilan Agama dalam menangani perkara ekonomi syari'ah ini meliputi:

1. Menunjuk arbiter dalam hal para pihak tidak dapat mencapai kesepakatan mengenai pemilihan arbiter atau tidak ada ketentuan yang dibuat mengenai pengangkatan arbiter (Pasal 13-15 UU No.30 Tahun 1999);

2. Memutus hak ingkar yang diajukan oleh para pihak atau salah satu dari mereka terhadap arbiter yang diangkat oleh Ketua Pengadilan Agama (Pasal 22-25 UU No.30 Tahun 1999);

3. Mendaftar keputusan Basyarnas yang harus didaftarakan dalam tempo 30 hari sejak putusan diucapkan (Pasal 59 UU No.30 Tahun 1999);

4. Melaksanakan keputusan badan alternatif penyelesaian sengketa (ADR) dan keputusan Basyarnas melalui eksekusi paksa manakala diperlukan (Pasal 59-63 UU No.30 Tahun 1999). Keputusan tersebut dapat dieksekusi oleh Pengadilan Agama manakala telah terdaftar sebelumnya di Kepaniteraan Pengadilan Agama selambat-lambatnya 30 hari setelah penandatanganan keputusan tersebut (Pasal 6 ayat (7) UU No.30 Tahun 1999). Apabila ketentuan ini tidak diindahkan maka keputusan tersebut tidak dapat dieksekusi (Pasal 59 ayat (4) UU No.30 Tahun 1999);

5. Menyatakan pailit debitur yang mempunyai dua atau lebih kreditur dan tidak membeyar sedikitnya satu utang yang telah jatuh waktu dan dapat ditagih (Pasal 1 ayat (1) UU No.4 Tahun 1998);

6. Memeriksa, memutus, dan menyelesaikan sengketa ekonomi syari'ah (Pasal 49 UU No.3 Tahun 2006). 
Achmad Fauzi: Urgensi Hukum Perikatan Islam...

\section{Langkah Penyelesaian Sengketa Ekonomi Syariah Melalui Litigasi}

Proses penyelesaian perkara ekonomi syari'ah melalui jalur litigasi dilakukan dengan terlebih dahulu memeriksa apakah syarat administrasi perkara telah tercukupi atau belum. Administrasi perkara ini meliputi berkas perkara yang di dalamnya telah ada panjar biaya perkara, nomor perkara, penetapan majelis hakim, dan penunjukan panitera sidang. Apabila syarat tersebut belum lengkap maka berkas dikembalikan ke kepaniteraan untuk dilengkapi, apabila sudah lengkap maka hakim menetapkan hari sidang dan memerintahkan kepada juru sita agar para pihak dipanggil untuk hadir dalam sidang yang waktunya telah ditetapkan oleh hakim dalam surat Penetapan Hari Sidang (PHS). Hakim memeriksa syarat formil perkara yang meliputi kompetensi dan kecakapan penggugat, kompetensi (kewenangan) Pengadilan Agama baik secara absolut maupun relatif, ketepatan penggugat menentukan tergugat (tidak salah menentukan tergugat), surat gugatan tidak obscuur, perkara yang akan diperiksa belum pernah diputus oleh pengadilan dengan putusan yang sudah berkekuatan hukum tetap (tidak ne bis in idem), tidak terlalu dini, tidak terlambat, dan tidak dilarang oleh undang-undang untuk diperiksa dan diadili oleh Pengadilan. Apabila ternyata para pihak telah terikat dengan perjanjian arbitrase, maka Pengadilan Agama tidak berwenang memeriksa dan mengadilinya (Pasal 3 UU No.30 Tahun 1999). Apabila syarat formil telah terpenuhi berarti hakim dapat melanjutkan untuk memeriksa pokok perkara. Dalam persidangan ini, tugas pertama dan utama hakim adalah berusaha mendamaikan kedua belah pihak sesuai dengan PERMA Nomor 1 Tahun 2008 tentang mediasi. Apabila tercapai perdamaian, maka hakim membuat akta perdamaian. Apabila tidak dapat dicapai perdamaian maka pemeriksaan dilanjutkan ke tahap berikutnya. Hakim melakukan konstatiring terhadap dalil-dalil gugat dan bantahannya melalui tahap-tahap pembacaan surat gugatan, jawaban tergugat, replik, duplik, dan pembuktian. Hakim melakukan kualifisiring melalui kesimpulan para pihak dan musyawarah hakim. Hakim melakukan konstituiring yang dituangkan dalam surat putusan.

Dalam memeriksa dan mengadili tingkat pertama sengketa ekonomi syariah, hukum perikatan Islam memang memiliki kedudukan penting. Sebab, segala bentuk peristiwa hukum mengenai kegiatan ekonomi syariah diawali dengan akad yang memuat hak dan kewajiban masing-masing pihak untuk mengikatkan diri dalam suatu perjanjian. Tanpa menguasai hukum perikatan Islam, mustahil hakim dapat memutus dan menyelesaikan sengketa ekonomi syariah dengan benar dan adil. Ambil contoh jenis-jenis kegiatan usaha Bank Umum Syariah yang di dalamnya tidak pernah terlepas dari akad;

1. Bank Umum Syariah menghimpun dana dalam bentuk simpanan berupa giro, tabungan, atau bentuk lainnya yang dipersamakan dengan itu berdasarkan akad wadi'ah atau akad lain yang tidak bertentangan dengan prinsip syariah;

2. Bank Umum Syariah menghimpun dana dalam bentuk Investasi berupa deposito, tabungan, atau bentuk lainnya yang dipersamakan dengan itu berdasarkan akad mudharabah atau akad lain yang tidak bertentangan dengan prinsip syariah; 
Achmad Fauzi: Urgensi Hukum Perikatan Islam...

3. Bank Umum Syariah menyalurkan pembiayaan bagi hasil berdasarkan akad mudharabah, akad musyarakah, atau akad lain yang tidak bertentangan dengan prinsip syariah;

4. Bank Umum Syariah menyalurkan pembiayaan berdasarkan akad murabahah, akad salam, akad istishna', atau akad lain yang tidak bertentangan dengan prinsip syariah;

5. Bank Umum Syariah menyalurkan pembiayaan berdasarkan akad qardh atau akad lain yang tidak bertentangan dengan prinsip syariah;

6. Bank Umum Syariah menyalurkan pembiayaan penyewaan barang bergerak atau tidak bergerak kepada nasabah berdasarkan akad ijarah dan/atau sewa beli dalam bentuk ijarah muntahiya bittamlik atau akad lain yang tidak bertentangan dengan prinsip syariah;

7. Bank Umum Syariah melakukan pengambilalihan utang berdasarkan akad bawalah atau akad lain yang tidak bertentangan dengan prinsip syariah;

8. Bank Umum Syariah melakukan usaha kartu debit dan/atau kartu pembiayaan berdasarkan prinsip syariah;

9. Bank Umum Syariah membeli, menjual, atau menjamin atas risiko sendiri surat berharga pihak ketiga yang diterbitkan atas dasar transaksi nyata berdasarkan prinsip syariah, antara lain, seperti akad ijarah, musyarakah, mudharabah, murabahah, kafalah, atau hawalab;

10. Bank Umum Syariah membeli surat berharga berdasarkan prinsip syariah yang diterbitkan oleh pemerintah dan/atau Bank Indonesia;

11. Bank Umum Syariah menerima pembayaran dari tagihan atas surat berharga dan melakukan perhitungan dengan pihak ketiga atau antarpihak ketiga berdasarkan prinsip syariah;

12. Bank Umum Syariah melakukan penitipan untuk kepentingan pihak lain berdasarkan suatu akad yang berdasarkan prinsip syariah;

13. Bank Umum Syariah menyediakan tempat untuk menyimpan barang dan surat berharga berdasarkan prinsip syariah;

14. Bank Umum Syariah memindahkan uang, baik untuk kepentingan sendiri maupun untuk kepentingan nasabah berdasarkan prinsip syariah;

15. Bank Umum Syariah melakukan fungsi sebagai wali amanat berdasarkan akad wakalah;

16. Bank Umum Syariah memberikan fasilitas letter of credit atau bank garansi berdasarkan prinsip syariah;

17. Bank Umum Syariah melakukan kegiatan lain yang lazim dilakukan di bidang perbankan dan di bidang sosial sepanjang tidak bertentangan dengan prinsip syariah dan sesuai dengan ketentuan peraturan perundang-undangan.

Ekonomi syariah merupakan yurisdiksi baru Pengadilan Agama. Istilah ekonomi syariah merupakan hal spesifik di Indonesia karena istilah tersebut hampir tidak dikenal di negara-negara Islam lainnya. Di banyak negara dan di lingkungan 
Achmad Fauzi: Urgensi Hukum Perikatan Islam...

akademik dikenal dengan istilah "Ekonomi Islam" atau "Islamic Economic" sebagai padanan dari istilah Arab "al-Iqtishadi al-Islami". ${ }^{5}$

Ekonomi syariah dapat didefinisikan perbuatan atau kegiatan usaha yang dilaksanakan menurut prinsip syariah ${ }^{6}$, antara lain meliputi bank syariah, lembaga keuangan mikro syariah, asuransi syariah, reasuransi syariah, reksadana syariah, obligasi syariah dan surat berharga berjangka menengah syariah, sekuritas syariah, pembiayaan syariah, pegadaian syariah, dana pensiun syariah, bisnis syariah dan lain-lain.

1. Bank syariah adalah lembaga keuangan yang usaha pokoknya memberikan pembiayaan dan jasa-jasa lain dalam lalu lintas pembayaran serta peredaran uang yang beroperasi disesuaikan dengan prinsip-prinsip syariah. Menurut pasal 1 angka 7 Undang-Undang No.21 tahun 2008 tentang Perbankan Syariah, menerangkan bahwa Bank Syariah adalah Bank yang menjalankan kegiatan usahanya berdasarkan prinsip syariah. ${ }^{7}$

2. BMT sebagai lembaga pendukung kegiatan ekonomi masyarakat kecil dengan berlandaskan syariah terdiri dari 2 istilah yakni baitul maal dan baitut tamwil. Baitul maal lebih mengarah pada usaha pengumpulan dan penyaluran dana nonprofit (ZIS). Baitut tamwil mengarah pada usaha pengumpulan dan penyaluran dana komersial. Kegiatan utama dari lembaga ini adalah menghimpun dana dan mendistribusikan kembali kepada anggota dengan imbalan bagi hasil atau mark-up/margin (sesuai syariah). Prinsip dan mekanismenya hampir sama dengan perbankan syariah hanya skala produk dan jumlah pembiayaannya terbatas. Latar belakang lahirnya BMT karena adanya kemiskinan massif, perbankan belum bisa akses ke masyarakat miskin, mayarakat miskin mendapatkan sumber dana mahal, lembaga/badan usaha yang ada belum sesuai dengan syariah, pemberdayaan masyarakat muslim melalui lembaga masjid, pembinaan pengembangan usaha masyarakat.

3. Dalam bahasa Belanda, Asuransi biasa disebut dengan istilah assurantie (asuransi) dan verzekering (pertanggungan). Dalam bahasa Arab istilah asuransi biasa diungkapkan dengan kata at-tamin yang secara bahasa berarti tuma'ninatun nafsi wa zawalul khauf, tenangnya jiwa dan hilangnya rasanya takut. Maksudnya, orang yang ikut dalam kegiatan asuransi, jiwanya akan tenang dan tidak ada rasa takut ataupun was-was dalam menjalani kehidupan, karena ada pihak yang memberikan jaminan atau pertanggungan.

Mengenai definisi asuransi secara baku dapat dilacak dari peraturan (perundang-undangan) dan beberapa buku yang berkaitan dengan asuransi.

${ }^{5}$ Abdurrahman (2008), Beberapa Catatan Sekitar Kompilasi Hukum Ekonomi Syariah Dalam Buku Kenangan Berjudul Bagir Manan Ilmuwan dan Penegak. Hukum (Kenangan Sebuab Pengabdian). hlm. 231.

${ }^{6}$ Prinsip syariah maksudnya prinsip hukum Islam dalam kegiatan perbankan berdasarkan fatwa yang dikeluarkan oleh lembaga yang berwenang dalam menetapkan fatwa di bidang syariah (lihat pasal 1 angka 12 Undang Undang No. 21 Tahun 2008 Tentang Perbankan Syariah).

${ }^{7}$ Menurut jenisnya Bank Syariah terdiri atas Bank Umum Syariah dan Bank Pembiayaan Rakyat Syariah. Bank Umum Syariah dalam kegiatannya memberikan jasa dalam lalulintas pembayaran. Sedangkan Bank Pembiayaan Rakyat Syariah tidak memberikan jasa dalam lalulintas pembayaran (lihat pasal 1 angka 8 dan 9 Undang Undang No. 21 Tahun 2008 Tentang Perbankan Syariah). 
Achmad Fauzi: Urgensi Hukum Perikatan Islam...

Muhammad Muslehuddin dalam bukunya Insurance and Islamic Law mengadopsi pengertian asuransi dari Encyclopaedia Britanica sebagai suatu persediaan yang disiapkan oleh sekelompok orang, yang dapat tertimpa kerugian, guna menghadapi kejadian yang tidak dapat diramalkan, sehingga bila kerugian tersebut menimpa salah seorang di antara mereka maka beban kerugian tersebut akan disebarkan ke seluruh kelompok. ${ }^{8}$

Lebih jauh Muslehuddin menjelaskan pengertian asuransi dalam sudut pandang yang berbeda, serta mengalami kesimpangsiuran. Ada yang mendefinisikan asuransi sebagai perangkat untuk menghadapi kerugian dan ada yang mengatakannya sebagai persiapan menghadapi risiko. Dilihat dari signifikansi kerugian, Adam Smith berpendapat bahwa asuransi dengan menyebarkan beban kerugian kepada orang banyak, membuat kerugian menjadi ringan dan mudah bagi seluruh masyarakat.

Dalam Kitab Undang-Undang Hukum Dagang (KUHD) pasal 246 dijelaskan bahwa yang dimaksud asuransi atau pertanggungan adalah "suatu perjanjian (timbal balik), dengan mana seorang penanggung mengikatkan diri kepada seorang tertanggung, dengan menerima suatu premi, untuk memberikan penggantian kepadanya, karena suatu kerugian, kerusakan, atau kehilangan keuntungan yang diharapkan, yang mungkin akan dideritanya, karena suatu peristiwa tak tentu (onzeleer vooral)."

Asuransi menurut UU RI No. 2 th. 1992 tentang Usaha Perasuransian, yang dimaksud dengan asuransi atau pertanggungan adalah perjanjian antara dua pihak atau lebih, dengan mana pihak penanggung mengikatkan diri kepada tertanggung, dengan menerima premi asuransi untuk memberikan penggantian kepada tertanggung karena kerugian, kerusakan, atau kehilangan keuntungan yang diharapkan, atau tanggung jawab hukum kepada pihak ketiga yang mungkin diderita tertanggung, yang timbul dari suatu peristiwa yang tidak pasti atau untuk memberikan suatu pembayaran yang didasarkan atas meninggal atau hidupnya seseorang yang dipertanggungkan.

Sedangkan pengertian asuransi syariah menurut fatwa DSN-MUI, yang lebih dikenal dengan ta'min, takaful, atau tadhamun adalah usaha saling melindungi dan tolong-menolong di antara sejumlah orang atau pihak melalui investasi dalam bentuk aset dan atau tabarru memberikan pola pengembalian untuk menghadapi risiko tertentu melalui akad yang sesuai dengan syariah .?

Dari definisi asuransi syariah di atas jelas bahwa pertama, asuransi syariah berbeda dengan asuransi konvensional. Pada asuransi syariah setiap peserta sejak awal bermaksud saling menolong dan melindungi satu dengan yang lain dengan menyisihkan dananya sebagai iuran kebajikan yang disebut tabarru'. Jadi sistem ini tidak menggunakan pengalihan risiko (transfer of risk) dimana

${ }^{8}$ Muhammad Muslehuddin (1999). Insurance and Islamic Law, Penerj: Burhan Wirasubrata, Menggugat Asuransi Modern: mengajukan suatu alternatif baru dalam perspektif hukum Islam, Lentera: Jakarta.

${ }^{9}$ Dewan Syariah Nasional (DSN) Majelis Ulama Indonesia (MUI), Fatwa Dewan Syariah Nasional No: 21/DSN-MUI/X/2001 tentang Pedoman Umum Asuransi Syariah, Jakarta; 2001. 
Achmad Fauzi: Urgensi Hukum Perikatan Islam...

tertanggung harus membayar premi, tetapi lebih merupakan pembagian risiko (sharing of risk) di mana para peserta saling menanggung. Kedua, akad yang digunakan dalam asuransi syariah harus selaras dengan hukum Islam (syari'ah), artinya akad yang dilakukan harus terhindar dari riba, gharar (ketidak jelasan dana), dan maisir (gambling), di samping itu investasi dana harus pada obyek yang halal-thoyibah.

Akad pada operasional asuransi syariah dapat didasarkan pada akad tabarri', yaitu akad yang didasarkan atas pemberian dan pertolongan dari satu pihak kepada pihak yang lain. ${ }^{10}$ Akad tabarru' merupakan bagian dari tabaddul haq (pemindahan hak). Walaupun pada dasarnya akad tabarru' hanya searah dan tidak disertai dengan imbalan, tetapi ada kesamaan prinsip dasar di dalamnya, yaitu adanya nilai pemberian yang didasarkan atas prinsip tolong-menolong dengan melibatkan perusahaan asuransi sebagai lembaga pengelolah dana.

Dengan akad tabarru' berarti peserta asuransi telah melakukan persetujuan dan perjanjian dengan perusahaan asuransi (sebagai lembaga pengelolah) untuk menyerahkan pembayaran sejumlah dana (premi) ke perusahaan agar dikelolah dan dimanfaatkan untuk membantu peserta lain yang kebetulan mengalami kerugian. Akad tabarru' ini mempunyai tujuan utama yaitu terwujudnya kondisi saling tolong-menolong antara peserta asuransi untuk saling menanggung (takaful) bersama. Zarqa tidak menyebutkan akad takaful dalam mengilustrasikan kondisi semacam ini, tetapi dengan memakai istilah akad tabarru'.11 Sebagai implikasinya, adalah peniadaan prinsip pertukaran (tabadduI) yang layak terjadi pada akad al-ba'i (jual-beli). Akad tabadduly adalah akad yang selama ini dipakai oleh perusahaan asuransi konvensional, yaitu memposisikan nasabah asuransi sebagai pembeli polis yang dikeluarkan oleh perusahaan asuransi, sedang pihak perusahaan adalah penjual polis yang harus dibayar melalui pembayaran premi. Akibat dari akad ini (tabaduly) adalah keharusan pemindahan hak.

Akad lain yang dapat diterapkan dalam bisnis asuransi adalah akad mudharabah, yaitu satu bentuk akad yang didasarkan pada prinsip profit and loss sharing (berbagi atas untung dan rugi), di mana dana yang terkumpul dalam total rekening tabungan (saving) dapat di-investasi-kan oleh perusahaan asuransi yang risiko investasi ditanggung bersama antara perusahaan dan nasabah.

Secara ringkas, dapatlah dikatakan bahwa dalam praktek asuransi paling tidak ada dua akad yang membentuknya, yaitu; akad tabarru' dan akad mudharabah. Akad tabarru' terkumpul dalam rekening dana sosial yang tujuan utamanya digunakan untuk saling menanggung (takaful) peserta asuransi yang mengalami musibah kerugian. Sedang akad mudharabah terwujud tetkala dana yang terkumpul dalam perusahaan asuransi itu diinvestasikan dalam wujud usaha yang diproyeksikan menghasilkan keuntungan (profit). Karena landasan dasar yang awal dari akad mudharabab ini adalah prinsip profit and loss sharing, maka jika dalam investasinya mendapat keuntungan, maka keuntungan tersebut dibagi

${ }^{10}$ Mustafa Ahmad Zarqa, al-madkhal al-figh al-'am, Juz I, (Beirut: Dar al-Fikr, 1968), hlm. 291.

${ }^{11} \mathrm{Ibid}$. 
Achmad Fauzi: Urgensi Hukum Perikatan Islam...

bersama sesuai dengan porsi (nisbah) yang disepakati. Sebaliknya jika dalam investasinya mengalami kerugian (loss atau negative return) maka kerugian tersebut juga dipikul bersama antara peserta asuransi dan perusahaan. ${ }^{12}$

4. Reksadana syariah adalah wadah yang dipergunakan untuk menghimpun dana dari masyarakat pemodal untuk selanjutnya diinvestasikan dalam portofolio efek (saham, obligasi, valuta asing, atau deposito) oleh Manajer Investasi yang pengelolaan dan kebijakan investasinya mengacu pada syariat Islam.

Manajer Investasi, dengan aqad Wakala, akan menjadi wakil dari Investor untuk kepentingan dan atas nama Investor. Sedangkan Reksa Dana Syariah akan bertindak dalam aqad Mudharabah sebagai Mudharib yang mengelola dana/harta milik bersama dari para Pemilik Harta. Sebagai bukti penyertaan Pemilik Dana akan mendapat Unit Penyertaan dari Reksa Dana Syariah. Tetapi Reksa Dana Syariah sebenarnya tidak bertindak sebagai Mudharib murni karena Reksa Dana Syariah akan menempatkan kembali dana ke dalam kegiatan Emiten melalui pembelian Efek Syariah. Dalam hal ini Reksa Dana Syariah berperan sebagai Shahibul Mal dan Emiten berperan sebagai Mudharib. Oleh karena itu hubungan ini disebut sebagai ikatan Mudharaba Bertingkat. Dalam kedua situasi tersebut Manajer Investasi akan memberikan jasa secara langsung atau tidak langsung kepada Investor yang ingin melakukan investasi mengikuti prinsip Syariah. Manajer Investasi juga harus mampu melakukan kegiatan pengelolan yang sesuai dengan Syariah. Sehingga diperlukan adanya panduan mengenai norma-norma yang harus dipenuhi oleh Manajer Investasi agar investasi dan hasilnya tidak melanggar ketentuan Syariah, termasuk ketentuan yang berkaitan dengan gharar dan maysir. Produk reksadana meliputi danareksa syariah yang bertujuan untuk memperoleh pertumbuhan investasi melalui investasi saham secara syariah Islam dan danareksa syariah berimbang yang bertujuan untuk memperoleh hasil investasi yang berkelanjutan dengan tingkat diversifikasi yang tinggi secara syariah Islam.

5. Obligasi syariah merupakan suatu surat berharga jangka panjang berdasarkan prinsip syariah yang dikeluarkan emiten kepada pemegang obligasi syariah yang mewajibkan emiten untuk membayar pendapatan kepada pemegang obligasi syariah berupa bagi hasil/margin/fee, serta membayar kembali dana obligasi pada saat jatuh tempo. Tentang obligasi syariah diatur dalam bab XXIV pasal 604 sampai dengan 607 KHES. Di samping itu ada pula obligasi syariah mudharabah yang diatur dalam bab XXI pasal 574 sampai dengan 579 KHES.

Sumber hukum obligasi syariah dapat ditilik dalam Firman Allah Swt., dalam QS al-Maidah [5]: 1

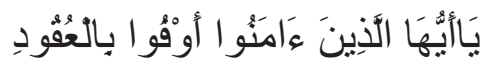

${ }^{12}$ Muhamad Nadratuzzaman Hosen dan AM Hasan Ali (2006), dalam makalahnya berjudul Kapita Selekta Asuransi Syariab: Telaah Umum Tentang Asuransi Syariah di Indonesia. Disampaikan dalam acara Seminar dan Lokakarya Mencari Format Ideal Kompilasi Hukum Ekonomi Syariah diselenggarakan oleh Tim Penyusun Kompilasi Ekonomi Syariah Mahkamah Agung RI pada tanggal 20 November 2006 di Hotel Grand Alia Cikini. hlm. 6-7.

Volume III, No. 1, Juli 2009 
Achmad Fauzi: Urgensi Hukum Perikatan Islam...

Artinya:

Hai orang yang beriman! Penubilah aqad-aqad itu (QS al-Maidab [5]: 1)

QS al-Israa [17]: 34

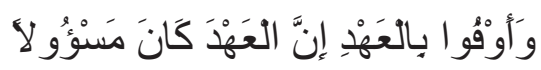

... dan penubilah janji, sesunggubnya janji itu pasti diminta pertanggungan jawabnya. (QS. Al-Israa [17]: 34).

QS al-Baqarah [2]: 275

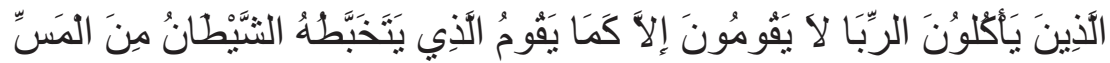

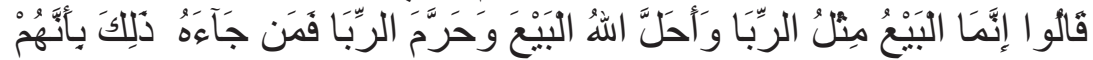

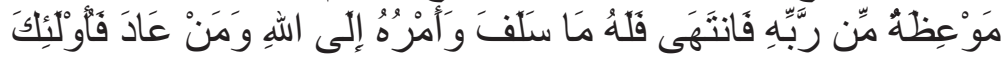

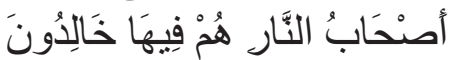

Orang-orang yang makan (mengambil) riba tidak dapat berdiri melainkan seperti berdirinya orangyang kemasukan syaitan lantaran (tekanan) penyakit gila. Keadaan mereka yang demikian itu, adalah disebabkan mereka berkata (berpendapat), sesunggubnya jual beli itu sama dengan riba. Orang-orang yang telah sampai kepadanya larangan dari Rabbnya, lalu terus berhenti (dari mengambil riba), maka baginya apa yang telah diambilnya dabulu (sebelum datang larangan); dan urusannya (terserab) kepada Allah. Orang yang mengulangi (mengambil riba), maka orang itu adalah pengbuni-pengbuni neraka; mereka kekeal di dalamnya. (QS. Al-Baqarah [2]: 275).

6. Dana pensiun syariah

Sunduq mu'asyat taqa'udi atau dana pensiun syariah adalah badan usaha yang mengelola dan menjalankan program yang menjanjikan manfaat pension berdasar prinsip syariah (pasal 20 angka 39 KHES). Hal ini diatur dalam bab XXIX Pasal 626 sampai dengan 673 KHES.

\section{Penutup}

Hakim pada prinsipnya tidak semata-mata mencari dan menemukan kebenaran formil. Termasuk dalam perkara keperdataan, hakim harus mampu menggali kebenaran materiil. Sehingga putusan-putusan yang dihasilkan mengarah kepada pembaharuan penemuan hukum (rechtsvinding) yang dibentuk berdasar metode penafsiran dan konstruksi hukum. Sengketa ekonomi syariah adalah yurisdiksi baru bagi Peradilan Agama dengan perangkat hukum yang belum sempurna, sehingga menuntut hakim untuk menggali nilai-nilai keadilan yang hidup dalam masyarakat. Perumusan putusan terhadap sengketa ekonomi syariah tidak bisa dilepaskan dari wawasan hukum perikatan Islam. Karena segala bentuk kegiatan usaha di bidang ekonomi syariah diawali dengan perjanjian dengan konsekuensi para pihak mematuhi dan mengikatkan diri terhadap isi perjanjian tersebut. Ini menjadi momentum yang baik bagi umat Islam untuk mengimplementasikan nilai-nilai ajaran Islam menyangkut hukum perikatan Islam. Ini penting mengingat sebelum terjadi amandemen UU No 7/1989, penegakkan 
Achmad Fauzi: Urgensi Hukum Perikatan Islam...

hukum kontrak bisnis di lembaga-lembaga keuangan syariah banyak mengacu pada ketentuan KUH Perdata yang merupakan terjemahan dari Burgerlijk Wetboek (BW), Kitab Undang-Undang Hukum Sipil Belanda yang dikonkordansi keberlakuannya di tanah Jajahan Hindia Belanda sejak tahun 1854, sehingga konsep perikatan Islam tidak berfungsi maksimal dalam praktek formalitas hukum di masyarakat.

\section{DAFTAR PUSTAKA}

Abdul Kadir Muhammad (1986), Hukum Perjanjian. Bandung: Alumni.

Abdurrahman (2008), Beberapa Catatan Sekitar Kompilasi Hukum Ekonomi Syariah, Dalam Buku Kenangan Berjudul Bagir Manan Ilmuwan dan Penegak. Hukum (Kenangan Sebuah Pengabdian). Jakarta: Mahkamah Agung RI.

Dewan Syariah Nasional (DSN) Majelis Ulama Indonesia (2001), Fatwa Dewan Syariah Nasional No: 21/DSN-MUI/X/2001 tentang Pedoman Umum Asuransi Syariah. Jakarta.

Muhammad Muslehuddin (1999). Insurance and Islamic Law, Penerj: Burhan Wirasubrata, Menggugat Asuransi Modern: mengajukan suatu alternatif baru dalam perspektif bukum Islam. Jakarta : Lentera.

Muhamad Nadratuzzaman Hosen dan AM Hasan Ali (2006), dalam makalahnya berjudul Kapita Selekta Asuransi Syariab: Telaab Umum Tentang Asuransi Syariah di Indonesia. Disampaikan dalam acara Seminar dan Lokakarya Mencari Format Ideal Kompilasi Hukum Ekonomi Syariah diselenggarakan oleh Tim Penyusun Kompilasi Ekonomi Syariah Mahkamah Agung RI pada tanggal 20 November 2006 di Hotel Grand Alia Cikini.

Mustafa Ahmad Zarqa (1968), al-madkhal al-fiqh al-'am. Beirut: Dar al-Fikr.

Peraturan Mahkamah Agung RI No. 1 Tahun 2008 tentang Mediasi. www.badilag.net

Peraturan Mahkamah Agung RI No. 02 Tahun 2008 tentang Kompilasi Hukum Ekonomi Syariah. www.badilag.net

Undang-Undang No. 21 Tahun 2008 tentang Perbankan Syariah. www.badilag.net

Undang-Undang No. 30 Tahun 1999 Tentang Arbitrase dan Alternatif Penyelesaian Sengketa. www.badilag.net 